\title{
Diatom activity within soft sediments: behavioural and physiological processes
}

\author{
Maria A. Saburova*, Igor G. Polikarpov
}

A. O. Kovalevsky Institute of Biology of the Southern Seas, Prospekt Nakhimova 2, Sevastopol 99011, Ukraine

\begin{abstract}
An investigation of vertical distribution, rhythms of vertical migration and division of epipelic free-living diatom algae was carried out at different sediment depths on intertidal sandflat in the Chernaya River Estuary (Kandalaksha Gulf, White Sea, Russia) during the summers of 1994-2001. The depth of penetration of viable microalgae cells in the sediment did not exceed $4.2 \mathrm{~cm}$ in the areas with clay sublayers, where zones with high negative Eh values were located closer to the surface. Diatom habitats in the areas with coarse sand sublayers extended to more than $8 \mathrm{~cm}$ depth. Approximately $40 \%$ of diatoms were present in the topmost $2 \mathrm{~mm}$ layer. The subsurface portion of diatom cells on average was concentrated within the layer with Eh values ranging from 0 to $-80 \mathrm{mV}$. Eh values below $-100 \mathrm{mV}$ limited diatom penetration in deep anoxic sediment layers. The deep portion of diatom populations consisted basically of dividing cells. A cytological analysis of diatom cell distribution showed that the proportion of cells in the different phases of mitosis increased with increasing depth, and reached 80 to $90 \%$ at a depth of 2 to $3 \mathrm{~cm}$. The regular presence of dividing diatom cells almost exclusively in aphotic anoxic sediments was noted first. The study of the dynamics of microphytobenthic vertical distribution revealed active diurnal vertical migration depending on temperature, light and tide regimes. The frequency of doublet cells (FDC) in epipelic diatom populations was in inverse proportion to cell concentrations in the photic zone. Diatom division was registered only during incubation in the porewater, which was rich in inorganic nutrients and dissolved organic matter. We suppose that a more stable habitat with higher concentrations of nutrients (especially nitrogen) in their more reduced forms $\left(\mathrm{NH}_{4}{ }^{+}\right.$instead of $\left.\mathrm{NO}_{3}{ }^{-}\right)$provides more favourable conditions for cell growth and division at the depth of several $\mathrm{cm}$ within the sediment compared, to the surface layer. Migration activity of diatom algae is an adaptation which permits cells to consume energy and to undergo fission under optimum conditions in spatially disconnected zones.
\end{abstract}

KEY WORDS: Epipelic diatoms · Vertical distribution · Vertical migration · Cell cycle · Intertidal sandflat Resale or republication not permitted without written consent of the publisher

\section{INTRODUCTION}

Diatoms are one of the major algal components of sand and mudflats (e.g. MacIntyre et al. 1996). The location of these microalgae within the thin photic zone of bottom sediment is determined by their photosynthetic activity. However, there are also numerous reports of viable microalgae cells or their photosynthetic pigments at significant depths, down to several $10 \mathrm{~s}$ of $\mathrm{cm}$ in the aphotic anaerobic zone in the different habitats, including in littoral and sublittoral bottom sediments of marine and freshwater basins (e.g. Grøntved 1962, Pamatmat
1968, Steele \& Baird 1968, Fenchel 1969, Wasmund 1969, Steele et al. 1970, Fenchel \& Straarup 1971, Branch \& Pringle 1987, MacIntyre et al. 1996).

To explain the presence of photosynthetic algae in aphotic anaerobic sediment zones, various hypotheses have been proposed: passive and active movement of organisms within the bottom sediments. It has been suggested that microalgae penetrate into the deeper sediment layers either during sediment resuspension (Steele et al. 1970, Gargas 1970, 1971, Round 1979, Baillie \& Welsh 1980, Branch \& Pringle 1987, MacIntyre et al. 1996) or by vertical movement in undisturbed sed- 
iments. There are numerous reports of the synchronic movement of microphytobenthos in sediment with similar conclusions. Benthic microalgae reach the surface of the sediment during a daytime emersion period and bury themselves deeper into sediment layers with the receding tide and/or the onset of night (e.g. FauréFremiet 1951, Ganaparti et al. 1959, Perkins 1960, Palmer \& Round 1967, Paterson \& Underwood 1990, Robak \& Kühl 1997, Kingston 1999). Fluctuations in photosynthetic rate, production and concentration of chlorophyll $a$ in the surface layer of the soft sediment coincide with the phases of tidal and day:night cycles (Marshall et al. 1971, Brown et al. 1972, Raiux-Gobin 1985, Guarini et al. 2000, Serôdio \& Catarino 2000). Such fluctuations are considered by these authors to be connected with microalgae vertical migration.

Fundamental questions concerning vertical distribution of microalgae in the sediment are: Why are photoautotrophs found outside the photic zone? What is their physiological state? How do photoautotrophs adapt to a long absence of light in oxygen-free conditions?

In this study, we investigated the vertical distribution of epipelic diatoms and their physiological activity within the sediment to better understand their behaviour mechanisms and their cell cycle regulation under environmental conditions which are atypical for photoautotrophs in the aphotic zone of intertidal sediments.

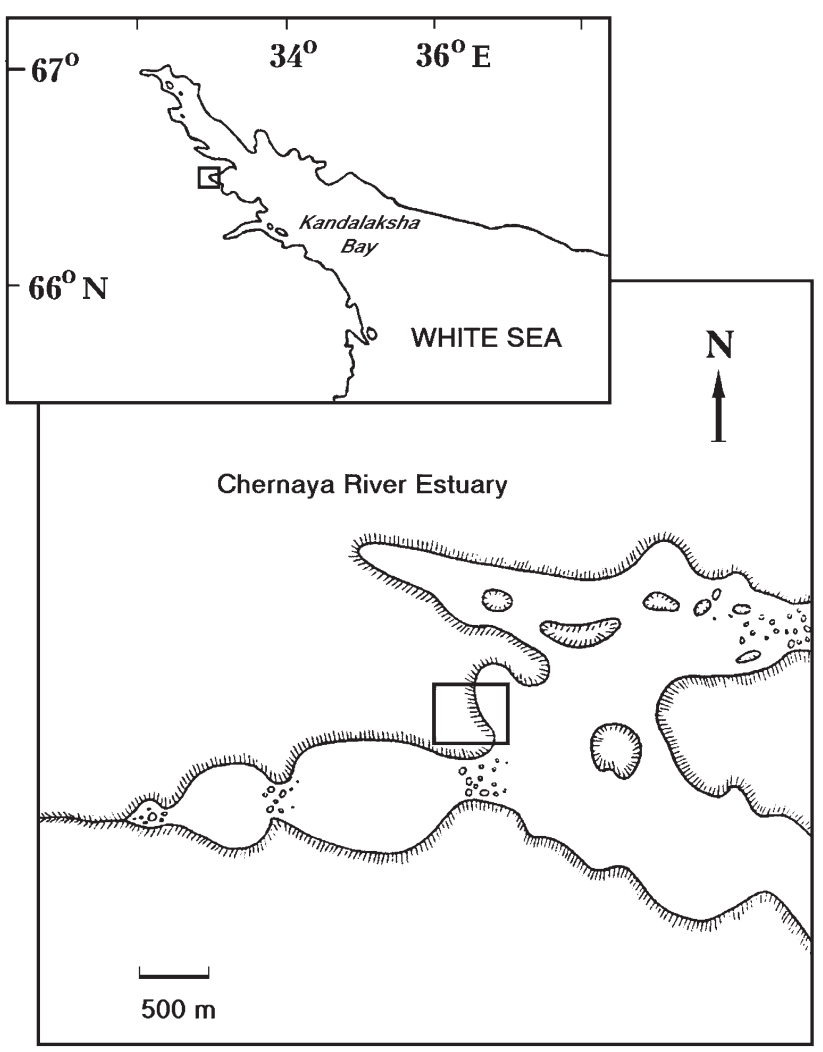

Fig. 1. Area of investigation White Sea, Russia

\section{MATERIALS AND METHODS}

Site description. The study was carried out in the gently sloping, low-energy, intertidal sandflat of the Chernaya River Estuary (Kandalaksha Gulf, White Sea, Russia) (Fig. 1) during the summers of 1994-2001. The sediment was fine-grained sand (modal particle size of 0.1 to $0.25 \mathrm{~mm}$ ), slightly silty (up to $15 \%$ of the aleuropelite fraction) and oligosaprobic (organic carbon content up to $4 \%$ of the sediment dry weight). The upper boundary of the reduced zone (redox potential, Eh $<0 \mathrm{mV}$ ) was found at a depth of 1 to $6-8 \mathrm{~cm}$ according to the type of sublayer (clay or coarse sand); the boundary of the photic zone $(>1 \%$ of total solar radiation) extended from 2.5 to $3.0 \mathrm{~mm}$. The emersion time at the sampling site was ca. $4 \mathrm{~h}$ during the single semi-diurnal tidal cycle and the tidal range was ca. $1.6 \mathrm{~m}$. A detailed survey examining the environmental characteristics of this sandflat was carried out by Burkovsky (1992).

Sampling procedures. Samples were collected from undisturbed sediments without infauna, stones or other physical irregularities on the middle intertidal area. A previous study revealed that such habitats are preferable for microphytobenthic development (Saburova et al. 1995). Samples were collected from microalgal patches (more than $10^{3}$ to $10^{4}$ cells $\mathrm{cm}^{-2}$ ) after preliminary sampling to estimate microalgal spatial distribution. Sediment cores were collected during the daytime emersion using plexiglass corers with an internal diameter of $2.6 \mathrm{~cm}$.

Vertical distribution profiles of epipelic diatoms were determined by collecting 21 cores (15 cm deep) during June to September, 1994 to 1998 . The sediment cores were sectioned every $2 \mathrm{~mm}$ and then at $5 \mathrm{~mm}$ intervals. The tops of the cores (upper $5 \mathrm{~cm}$, in several cases the upper $10 \mathrm{~cm}$ depending on sediment type) were used for the analysis.

To study the microalgae response to sediment burial, a field experiment was conducted July 17 to 22, 1992. A $4 \mathrm{~cm}$ layer of sterilized sand was placed over the natural sediment surface during the daytime emersion. A plastic frame prevented the added sediment layer from being washed out (the experimental phases are shown in Fig. 4). One core from both the sublayer natural sediment and the added upper layer of sand were collected on Days 1 and 5. Sediment cores were sectioned at $5 \mathrm{~mm}$ intervals to a depth of $4 \mathrm{~cm}$. The dynamics of diatom vertical distribution were analyzed.

The vertical migration of epipelic diatoms in the sediment was investigated from June to September 1995-2001 in 14 time series (Table 1). These studies represented 2 different situations occurring in this polar region: the so-called 'white-nights' (a night 
without full darkness) when there is no true day:night cycle (up to July) and normal day:night cycles (from August). The bottoms of the plexiglass corers with intact sediment cores were sealed, placed in the boxes with seawater and exposed to natural solar radiation intensity and temperature. Approximately $3 \mathrm{~cm}$ of water overlaid the sediment at the time of the experiments. Previous studies have revealed that microalgae migration rhythms do not change after the removal of sediment cores from natural conditions. Algal cells continued to migrate towards and away from the sediment surface in the absence of external stimuli under laboratory conditions for several days (e.g. Perkins 1960, Palmer \& Round 1967, Serôdio et al. 1997). Changes in the vertical profiles of the diatoms were determined by an analysis of randomly chosen cores every 2 to $6.5 \mathrm{~h}$ during the observation period. The cores were sectioned into 2 layers $(0$ to 3 and 3 to $50 \mathrm{~mm}$, corresponding to the photic and aphotic zones of this sediment type-Series 2 and 6) or into 0 to $3 \mathrm{~mm}$ and then at $10 \mathrm{~mm}$ intervals to a depth of $53 \mathrm{~mm}$ (Series 3 to 5 and 7 to 14). In Series 1 sediment cores were sectioned at $2 \mathrm{~mm}$ intervals to a depth of $50 \mathrm{~mm}$.

Enumeration of diatom cells. The modified method of Uhlig (1968) with filtered seawater instead of ice was used to extract the microalgae from the sediment. Microalgae cells were counted in vivo in culture dishes at a magnification of $56 \times$ with a Lomo MBS-9 stereomicroscope in randomly selected fields of view immediately after the extraction. The most abundant and large $(60$ to $100 \mu \mathrm{m})$ species of epipelic diatoms (Pleurosigma aestuarii, Donkinia recta, Entomoneis paludosa, Plagiotropis lepidoptera, Navicula humerosa, Hantzschia virgata were analyzed.
Cell cycle study. In diatoms generally, there is a 1 to $2 \mathrm{~h}$ post-cytokinesis stage between mitosis and G1, devoted to the formation of the silicon frustule, during which the daughter cells remain attached and grow in size (Vaulot et al. 1986). The number of such doublet cells within a population was determined microscopically in vivo while counting total diatom abundance. At least 300 cells were examined per sample.

A total of 19 intact sediment cores were collected for cytological analysis during June to August, 1995-1999. Cores were sectioned into $5 \mathrm{~mm}$ thick layers up to $35 \mathrm{~mm}$ and fixed with Navashin's fixative (Jensen 1962). The sequential decantation method was used to separate diatom cells from the sediment particles. Cells from each layer were mounted on glass microscope slides and stained with carmine acid according to Schneider (Jensen 1962). The cell cycle phase for each cell was determined by the degree of chromatin condensation in the cell nucleus at a magnification of $1500 \times$ with a JenaLumar microscope (Jena). Nuclei of large $(60$ to $100 \mu \mathrm{m})$ epipelic diatoms were close-cut separated according to cell cycle stage. From the caryological analysis we distinguished 3 well-defined cell cycle stages: interphase (I), mitosis (M) and cytokinesis + post-cytokinesis (C). Weakly stained nuclei with clearly visible chromatin grains were attributed to I; during $M$ strongly stained and packed nuclei were observed; doublet nuclei within 1 cell or doublet cells were determined as C. Four abundant epipelic diatom species (Pleurosigma aestuarii, Donkinia recta, Entomoneis paludosa and Plagiotropis lepidoptera) were selected for examination.

Effect of environmental factors on diatom division. To define the optimum conditions for vegetative division of epipelic diatoms a laboratory experiment was

Table 1. Time series, date, time, interval and number (n) of observations, mean values and amplitudes of temperature and solar radiation intensity at the sediment surface

\begin{tabular}{|clcccrc|}
\hline Series & Date & $\begin{array}{c}\text { Time } \\
(\mathrm{h})\end{array}$ & $\begin{array}{c}\text { Interval } \\
(\mathrm{h})\end{array}$ & $\mathrm{n}$ & $\begin{array}{c}\text { Temp. }\left({ }^{\circ} \mathrm{C}\right) \\
\text { Mean }(\min -\max )\end{array}$ & $\begin{array}{c}\text { Radiation intensity }\left(\text { lux } \times 10^{3}\right) \\
\left(\text { lux } 10^{3}\right) \text { Mean }(\min -\max )\end{array}$ \\
\hline 1 & Jul 21-23, 1989 & $36: 00$ & $6: 00$ & 8 & $5.9(4.0-12.0)$ & $4.6(0.25-20.0)$ \\
2 & Jul 9-10,1995 & $36: 00$ & $6: 00$ & 7,3 replicates & $16.6(7.5-23.0)$ & $16.5(0.03-36.0)$ \\
3 & Jul 12-14, 1995 & $52: 00$ & $6: 30$ & 9 & $12.5(6.0-18.0)$ & $7.8(0.8-22.0)$ \\
4 & Jul 16-17, 1995 & $44: 00$ & $5: 30$ & 9 & $14.3(8.0-22.0)$ & $12.2(0.3-40.0)$ \\
5 & Sep 18-20, 1995 & $50: 00$ & $5: 00$ & 11 & $5.5(-3.0-13.5)$ & $4.2(0.0-20.0)$ \\
6 & Aug 27-28, 1996 & $32: 00$ & $2: 30$ & 14,3 replicates & $16.7(9.0-25.5)$ & $12.7(0.0-55.0)$ \\
7 & Aug 31-Sep 1, 1996 & $30: 00$ & $5: 00$ & 7 & $15.4(6.0-28.0)$ & $9.6(0.0-41.0)$ \\
8 & Aug 31-Sep 1, 1998 & $23: 00$ & $3: 20$ & 8 & $6.8(0.0-14.2)$ & $16.5(0.0-59.0)$ \\
9 & Sep 6-7, 1998 & $24: 00$ & $4: 00$ & 7 & $9.9(3.0-16.8)$ & $6.3(0.25-20.0)$ \\
10 & Jun 17-18, 1999 & $33: 00$ & $3: 00$ & 12,2 replicates & $18.6(11.8-26.2)$ & $25.7(0.08-60)$ \\
11 & Aug 8, 2001 & $12: 00$ & $2: 00$ & 7 & $17.6(13.0-22.6)$ & $8.7(0.0-21.0)$ \\
12 & Aug 15, 2001 & $24: 00$ & $4: 00$ & 7 & $8.0(2.8-16.0)$ & $3.0(0.0-15.0)$ \\
13 & Aug 22-23, 2001 & $24: 00$ & $4: 00$ & 7 & $11.3(1.5-20.0)$ & $11.6(0.0-35.0)$ \\
14 & Sep 13-14, 2001 & $20: 00$ & $5: 00$ & 5 & $8.4(0.0-14.0)$ & $14.2(0.0-41.2)$ \\
\hline
\end{tabular}


conducted in July 1998. The topmost $3 \mathrm{~mm}$ photic layer of the natural undisturbed sediment was collected during the daytime emersion, when the maximum concentration of diatoms on the surface was observed. Plexiglass corers with the collected sediment were exposed to different conditions (phases of the experiment are shown in Table 5). The diatom cells were extracted from the sediment after exposure to these various conditions and the intensity of division (frequency of dividing cells) was estimated.

Physical sampling. Redox potential (Eh, mV) was measured using a pH-meter equipped with a $0.5 \mathrm{~mm}$ combined platinum electrode at $2 \mathrm{~mm}$ depth intervals. Grain-size analysis was performed on the upper $10 \mathrm{~cm}$ of the sediment at $0.5 \mathrm{~cm}$ depth intervals. The dried sediment was sieved onto a separator with mesh sizes $0.1,0.25,0.5$, and $1 \mathrm{~mm}$. The environmental conditions (temperature $\left[{ }^{\circ} \mathrm{C}\right]$, solar radiation intensity [lux] of the sediment surface, and tidal cycle) during the periods of diatom vertical migration observations were recorded. The tidal cycle values (h) were expressed as time from beginning of emersion ( 0 to $4 \mathrm{~h}$ : emersion; 4 to $12 \mathrm{~h}$ : submersion; 2 h: low water; 8 h: high water).

Data analysis. As most diatoms studied show high microspatial variability (Saburova et al. 1995), diatom abundance in each layer was expressed as a percentage of total density per core, to account for variability among the replicate cores. The dominating diatom species in each core were used for the analysis.

Diatom vertical distributions were presented as the percentage of the total population counted in each layer of the core. Vertical movements of microalgae within the sediment were estimated from the dynamics of the surface abundance. To estimate the vertical pattern of a cell cycle the results for each diatom population were expressed as the percentage of cells in each stage of the cell cycle from the total number of cells in each layer. The frequency of doublet cells (FDC) for each diatom population was calculated as a percentage of the doublet dividing cells from the total number of cells in the core and used as an indicator of vegetative cell division intensity.

Correlation analysis (Pearson's correlation coefficient) was performed to determine whether there were any significant changes in diatom cell cycle patterns with depth. We used stepwise multiple regression analysis, including momentary and daily (serial) mean values of temperature and solar radiation intensity of the sediment surface and tide cycle and all their combinations, to evaluate relationships between the measured factors and relative abundance of diatom cells in sediment surface. The 2 -sample $\chi^{2}$-test was employed to compare the frequency distribution of cell cycle stages between the surface and deep sediment layers. In other cases Student's $t$-test was used to check significance of the differences between the means. A critical p-value of $<0.05$ was always applied.

All statistical tests and procedures were undertaken using SYSTAT for Windows, Version 7.0 (SYSTAT) and SigmaPlot for Windows, Version 4.01 (SPSS).

\section{RESULTS}

\section{Vertical distribution of diatom cells}

Two different types of habitats were present in the studied intertidal sandflat: sediment with clay, and sediment with coarse sand as a sublayer (Types A and $B$, respectively). These sublayers occurred deeper than $10 \mathrm{~cm}$ (Burkovsky 1992). The vertical distribution of epipelic diatom total abundance in comparison with the vertical Eh profiles and granulometric composition of the different types of the sediment are shown in Fig. 2. The vertical distribution of diatoms was not uniform: approximately $40 \%$ of the diatoms were present in the topmost $2 \mathrm{~mm}$ layer, whereas a significant percentage (more than $60 \%$ ) was found in deep layers of the sediment. Maximum recorded depths of penetration of viable diatom cells into the sediment were $42 \mathrm{~mm}$ in Type A sediment and $83 \mathrm{~mm}$ in Type B. The subsurface portion of diatom cells was concentrated on average within the layer with Eh values from 0 to $-80 \mathrm{mV}$, at a depth of around 15 to $35 \mathrm{~mm}$ for Type A and 35 to $70 \mathrm{~mm}$ for Type B. Eh values below $-100 \mathrm{mV}$ limited diatom penetration into the deep anoxic sediment layers.

The granulomentric composition was similar in the topmost $6.5 \mathrm{~cm}$ layers for both sediment types. Significant differences were observed deeper than $6.5 \mathrm{~cm}$. The fine fraction $(<0.25 \mathrm{~mm})$ increased $1.3 \times$ within the 65 to $100 \mathrm{~mm}$ layer in comparison with the topmost 0 to $65 \mathrm{~mm}$ layer in Type A sediment. In contrast, the coarse fraction $(>0.5 \mathrm{~mm})$ content in Type B sediment increased more than $2 \times$.

\section{Division of diatom cells in the deep aphotic zone}

Vegetative cell division has been observed in large living diatom cells without cytological stains (Cox 1981, Pickett-Heaps 1998). Whilst counting living diatom cells from different sediment layers, we often found clearly visible doublet cells in the cytokinesis and post-cytokinesis stages (>200 observations were made between 1994 and 2001) often in significant numbers (up to $60-80 \%$ of the total number of cells in a layer). These cells were almost exclusively associated with the aphotic anoxic zone of the sediment. 


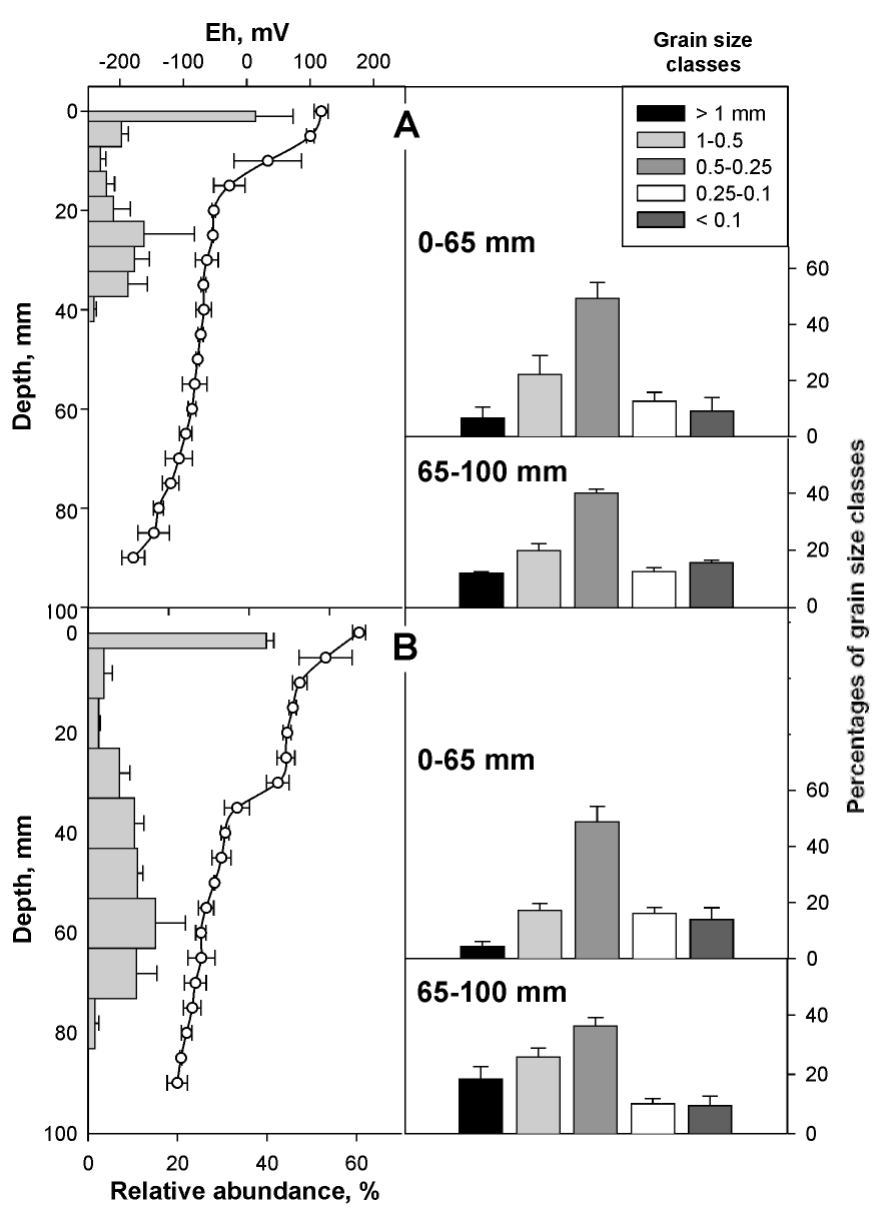

Fig. 2. Vertical profiles of epipelic diatom total abundance (grey horizontal bars) and Eh (- - - ) (left plots) and granulometric composition of sediments from topmost $65 \mathrm{~mm}$ and 65 to $100 \mathrm{~mm}$ layers (vertical bars, right plots) from different intertidal sandflat sites. Sediments with (A) clay sublayer and (B) coarse sand sublayer. A total of 33 cores were collected during daytime emersion periods in July 1992, July 1994 and June 1995. Error bars represent SE of the mean within replicate cores: (A) 8 and (B) 5 for diatom abundance estimation; 5 and 7 for Eh and 4 and 5 for granulometric composition estimations

FDCs varied strongly among diatom species and cores collected at different times of day (Table 2). Three examples of the daily pattern of the nondividing and dividing cells in the vertical distribution of Donkinia recta are shown in Fig. 5.

Percentages of the diatom abundance in $2 \mathrm{~mm}$ thick layers from the sediment surface to the depth of $35 \mathrm{~mm}$ were compared to the patterns of cell cycle stages within each $5 \mathrm{~mm}$ thick sediment layer (Fig. 3). All the diatom species examined demonstrated similar vertical distribution: about 40 to $60 \%$ of the cells were present in the photic zone, while the other parts of the populations were dispersed over the aphotic zone down to $35 \mathrm{~mm}$ (Fig. 3, left-hand panels). Patterns of cell cycle stages in the surface and deep parts of the population were not similar. The percentage of nondividing cells (I) decreased and the percentage of dividing cells $(\mathrm{M}+\mathrm{C})$ increased with depth. Similar vertical distributions were observed in each diatom species (Fig. 3, right-hand panels).

Table 3 shows the mean percentage of cell cycle stages in the topmost $5 \mathrm{~mm}$ (corresponding to the photic zone) and the deeper 5 to $35 \mathrm{~mm}$ layers (the aphotic zone). The patterns of the cell cycle stages between the upper (photic) and deep (aphotic) sediment layers were significantly different (2-sample $\chi^{2}$-test; $\left.\mathrm{p}<0.001\right)$ for all diatom species examined (Table 3). The percentage of cytokinetic cells in Pleurosigma aestuarii and Donkinia recta correlated significantly with depth. A noticeable tendency was obtained in the case of Entomoneis paludosa. The percentage of cells in the interphase correlated significantly and negatively with depth in these 3 diatom species. There was no linear correlation between frequency of mitosis and depth, except for E. paludosa. Insignificant correlation coefficients for Plagiotropis lepidoptera may have resulted from insufficient data.

\section{Vertical movement of diatom cells within the sediment}

\section{Response to burial in the sediment}

The migratory behaviour of the epipelic diatoms buried in the sediment is shown in Fig. 4. Microalgae demonstrated the ability to avoid unfavourable conditions by long-term burying. The experiment estimated the maximum rate of microalgae movement at $1.7 \mathrm{~mm}$ $\mathrm{h}^{-1}$. We detected buried cells on the surface of the sterilized sand ( $4 \mathrm{~cm}$ layer) within the first $24 \mathrm{~h}$ of the experiment. Of the initial microalgae abundance, $61 \%$ moved into the upper sediment layer after $24 \mathrm{~h}$. Upward migration of diatoms leads to practically full renewal of their disturbed vertical distribution over 5 d. However, $22.4 \%$ of the cells were still in the buried layer of the sediment (40 to $75 \mathrm{~mm}$ ) $5 \mathrm{~d}$ later. Vegetative division of the epipelic diatoms occurred only within natural sediment, and stopped after the migration of cells into the upper sterilized sand.

Table 2. Percentage of frequency of doublet cells (FDC) for different epipelic diatoms, n: number of replicates

\begin{tabular}{|lcccr|}
\hline Diatom species & Mean \pm SD & Min & Max & $\mathrm{n}$ \\
\hline Entomoneis paludosa & $8.26 \pm 7.80$ & 1.21 & 36.4 & 198 \\
Pleurosigma aestuarii & $15.72 \pm 19.10$ & 0.87 & 72.2 & 37 \\
Donkinia recta & $19.30 \pm 17.22$ & 0.63 & 71.4 & 56 \\
\hline
\end{tabular}




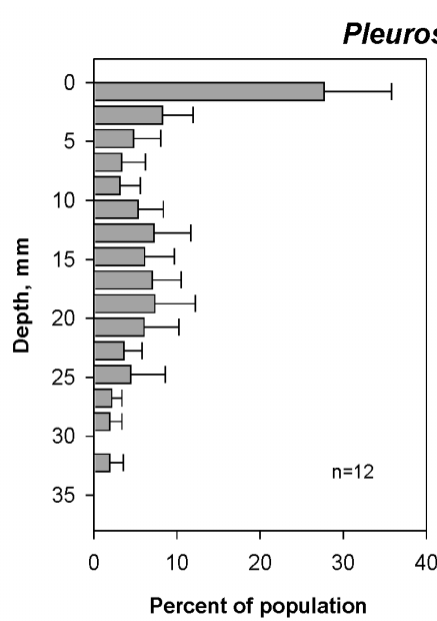

Pleurosigma aestuarii

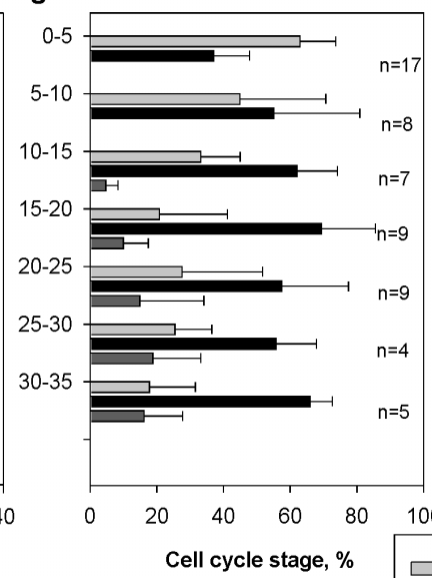

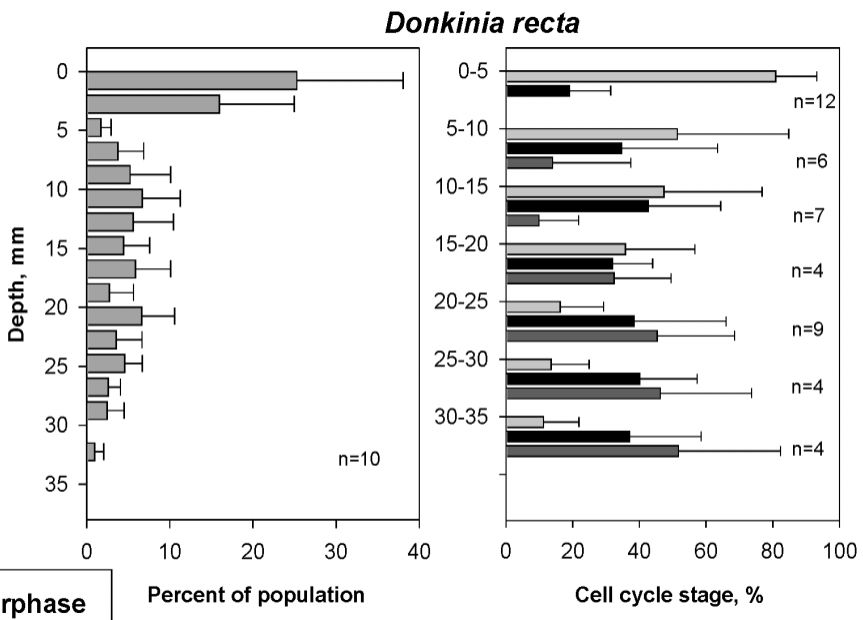

Entomoneis paludosa
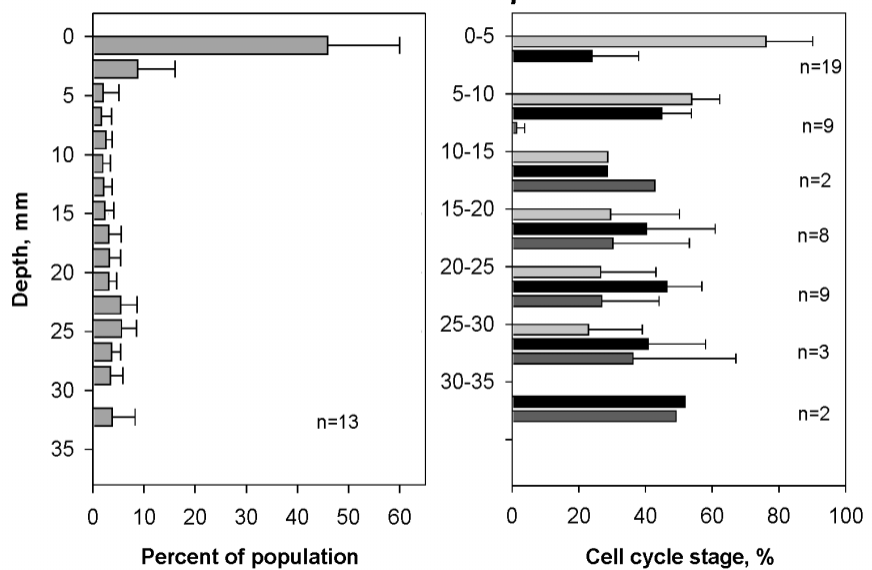

cytokinesis

\section{Plagiotropis lepidoptera}

Fig. 3. Vertical profiles of relative abundance (left-hand panels; mean \pm SE) and cell cycle patterns of epipelic diatoms. Cores were collected in June to September, 1994-1998. The length of each bar in left-hand panels is the percentage of the total population found in each depth interval. The length of each bar in right-hand panels is the percentage of the total cell number found in each layer. Error bars represent SE for replicate cores (left-hand panels) and replicate layers (right-hand panels). Number of replicates (n) was indicated within plots

Vertical migration of epipelic diatoms in the sediment

Analysis of daily patterns of microalgae vertical distribution and of environmental factors (solar radiation intensity, temperature and tidal cycle) during 14 time series (Table 1) revealed similar vertical migration of all the examined epipelic diatoms.

A detailed analysis of the vertical distribution dynamics was conducted for Entomoneis paludosa, the most abundant diatom (on average $10^{4}$ cells $\mathrm{cm}^{-2}$ ) on the examined intertidal sandflat. The resulting stepwise multivariate regression model explaining $39 \%$ of the total variation revealed $T_{\text {ser }}, H$ and $T \times L / T_{\text {ser }}$ variables to be significant (Table 4). E. paludosa demonstrated circadian rhythms of vertical migration within the sediment. Relative abundance of the cells in the sediment surface reached its maximum on warm days during low water. The colder the day, the higher the combined effect of temperature and light exposure of the sediment surface.

\section{Epipelic diatom rhythms of division}

We recorded epipelic diatom rhythms of division in each time series during our observations of vertical migration. A certain portion of the diatom cells was always undergoing vegetative division (Table 2). Dividing cells of epipelic diatoms were associated with the aphotic deep layer of the intertidal sediment. However, the frequency of the dividing cells varied greatly. A typical example of the vertical profiles for Donkinia recta during the day is shown in Fig. 5. D. recta cells were concentrated on the sediment surface during the daytime emersion $(76.2 \%$ in the topmost $2 \mathrm{~mm})$ and went deeper into the sediment at nightfall (Fig. 5). 
Table 3. Analysis of upper photic layer (0 to $5 \mathrm{~mm}$ ) versus deep aphotic layer (5 to $35 \mathrm{~mm}$ ) differenes in frequency distribution of cell cycle stages for 4 epipelic diatoms. Cell cycle stages: $I$, interphase; $M$, mitosis; $C$, cytokinesis and post-cytokinesis; $\mathrm{m}$, total number of examined cells. The results of 2-sample $\chi^{2}$-test for differences between cell cycle stage patterns in upper and deep layers and the Pearson's correlation coefficients for the relationship between stages of the cell cycle and depth are given. All $\chi^{2}$-values are significant at $\mathrm{p}<$ 0.001 level, $\mathrm{df}=2$ and Pearson's correlation coefficients in bold are statistically significant at $\mathrm{p}<0.05$

\begin{tabular}{|c|c|c|c|c|}
\hline \multirow[t]{2}{*}{$\begin{array}{l}\text { Diatom species } \\
\text { Cell cycle stage }\end{array}$} & \multicolumn{2}{|c|}{$\begin{array}{c}\text { Frequency distribution of } \\
\text { cell cycle stages (mean } \pm \mathrm{SE} \text { ) }\end{array}$} & \multirow{2}{*}{$\begin{array}{c}\text { 2-sample } \\
\chi^{2} \text {-test } \\
\text { values }\end{array}$} & \multirow{2}{*}{$\begin{array}{c}\text { Pearson's } \\
\text { correlation } \\
\text { coefficient }\end{array}$} \\
\hline & $0-5 \mathrm{~mm}$ & $5-35 \mathrm{~mm}$ & & \\
\hline \multicolumn{5}{|c|}{ Pleurosigma aestuarii } \\
\hline I & $62.94 \pm 3.08$ & $29.95 \pm 3.39$ & & -0.849 \\
\hline M & $37.06 \pm 3.08$ & $60.41 \pm 2.88$ & & 0.565 \\
\hline $\mathrm{C}$ & 0 & $9.63 \pm 2.01$ & 232.7 & 0.987 \\
\hline $\mathrm{m}$ & 740 & 1139 & & \\
\hline \multicolumn{5}{|l|}{ Donkinia recta } \\
\hline I & $80.91 \pm 3.90$ & $31.77 \pm 4.92$ & & -0.987 \\
\hline $\mathrm{M}$ & $19.09 \pm 3.90$ & $37.69 \pm 3.97$ & & 0.731 \\
\hline $\mathrm{C}$ & 0 & $30.55 \pm 4.76$ & 359.3 & 0.960 \\
\hline $\mathrm{m}$ & 627 & 600 & & \\
\hline \multicolumn{5}{|c|}{ Entomoneis paludosa } \\
\hline I & $76.10 \pm 3.90$ & $32.38 \pm 4.03$ & & -0.867 \\
\hline M & $23.90 \pm 3.90$ & $43.27 \pm 2.72$ & & 0.884 \\
\hline $\mathrm{C}$ & 0 & $24.39 \pm 4.60$ & 352.2 & 0.665 \\
\hline $\mathrm{m}$ & 647 & 1015 & & \\
\hline \multicolumn{5}{|c|}{ Plagiotropis lepidoptera } \\
\hline I & $86.30 \pm 3.96$ & $39.99 \pm 9.42$ & & -0.368 \\
\hline M & $13.70 \pm 3.96$ & $50.86 \pm 9.07$ & & 0.579 \\
\hline $\mathrm{C}$ & 0 & $9.09 \pm 4.18$ & 65.5 & -0.058 \\
\hline $\mathrm{m}$ & 146 & 124 & & \\
\hline
\end{tabular}

Fenchel 1969, Martens et al. 1978, Langner-van Voorst \& Höpner 1996, Landén \& Hall 1998).

\section{DISCUSSION}

Benthic microalgae are typically associated with the topmost sediment layer corresponding to the photic zone (e.g. Hopkins 1963, Fenchel 1969, MacIntyre et al. 1996). The depth of a $1 \%$ light level in the sediments varies from 0.1 to $13.2 \mathrm{~mm}$ and depends on the granulometry and organic content of the sediments (MacIntyre et al. 1996). Nevertheless, viable cells and/ or chlorophyll a have been observed to a depth of $10 \mathrm{~cm}$ (Grøntved 1962, Pamatmat 1968), 14 to $15 \mathrm{~cm}$ (Fenchel 1969, Fenchel \& Straarup 1971), and 20 to $30 \mathrm{~cm}$ (Steele \& Baird 1968, Branch \& Pringle 1987) on intertidal sandflats; to a depth of $30 \mathrm{~cm}$ (Steele et al. 1970) on a subtidal sandflat and 7.3 to $9.5 \mathrm{~cm}$ (Wasmund 1969) on a freshwater subtidal sandflat.

Typical patterns of diatom vertical distribution in sediment examined during the daytime emersion included the surface-associated peak of abundance formed by 40 to $60 \%$ of

After descending, cells of D. recta started to divide intensively. FDC varied from $4.76 \%$ during the daytime emersion up to $25.9-43.3 \%$ during the nighttime emersion and submersion.

Frequencies of the dividing cells in the examined diatom populations were in inverse proportion to the number of cells in the photic zone (Fig. 6).

\section{Optimum environment for epipelic diatom division}

The undisturbed topmost sediment layers containing microalgae were exposed to different conditions to determine the optimum environment for epipelic diatom cell division. The results are shown in Table 5. Vegetative division was registered only during incubation in porewater, which was rich in inorganic nutrients and DOM. As can be seen from Table 5, negative Eh values were not necessary for successful vegetative division of the diatom cells. However, in contrast with laboratory conditions, high concentrations of the nutrients in interstitial water have been observed in deep anoxic layers of natural intertidal sediments (e.g. microalgae total abundance (Figs. 2 to 5). The subsurface portion of cells was dispersed within the sediment depending on the sublayer properties, which determined the depth of the redox zone location. Comparison of the vertical profiles of diatom abundances in Fig. $2 \mathrm{~A}, \mathrm{~B}$ shows that the cells were dispersed over a greater range of depths in Type B sediment $(83 \mathrm{~mm})$, than in Type A (42 mm).

Cell cycle patterns of epipelic diatoms along depth (Fig. 3) revealed major differences between the surface- and the subsurface-associated portions of diatom populations. The predominance of nondividing cells near the sediment surface and the increase in the percentage of dividing cells with depth, as well as occurrence of cytokinetic cells only in deep layers (Fig. 3, Table 3), led us to assume a physiological heterogeneity of the microalgal populations at different depths of the sediment. A border between the physiologically different portions of diatom populations was located near the redox potential discontinuity layer (oxic/ anoxic interface, $\mathrm{Eh}=0 \mathrm{mV}$ ). We believe the present study to be the first report on the occurrence of diatom cell division in only the deep layers of intertidal sedi- 


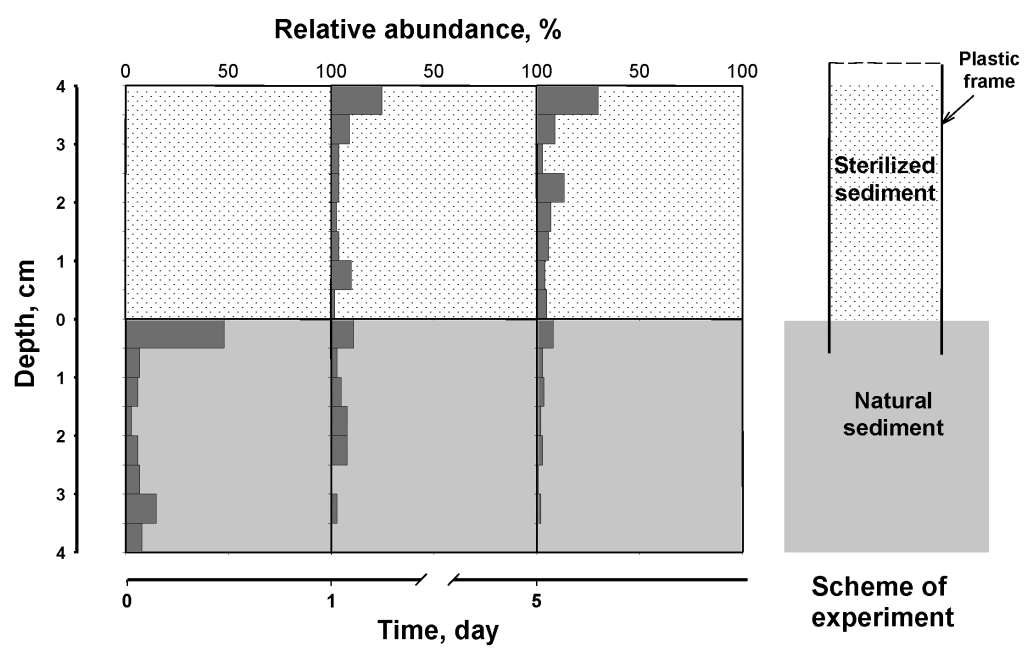

Fig. 4. Dynamics of epipelic diatom vertical distribution under artificial burial conditions: within natural sediments (lower panels) and sterilized sand (upper panels). A core from each type of the sediment $(40 \mathrm{~mm}$ of each) was collected during July 17 to 22, 1992

ments. Correlation analysis showed that percentages of interphasic and cytokinetic cells were significantly correlated with depth: the percentage of interphasic cells decreased and that of dividing cells increased with depth (Table 3).

Our investigations showed that the epipelic diatoms were able to avoid unfavourable burial conditions by active upward migration to the surface. Nevertheless, the initial vertical distribution was not restored even $5 \mathrm{~d}$ after the start of burial, and a portion of cells remained in the buried layers (Fig. 4). We assume that the establishment of destroyed vertical gradients of the sediment environment was a slow process, which allowed diatoms to expand their zone of the habitation whilst extremely negative Eh values were absent.

Table 4. Entomoneis paludosa. Results of stepwise multiple regression analysis between relative abundance of cells in the photic zone of the sediment and temperature $\left({ }^{\circ} \mathrm{C}\right)$ of sediment surface $(T)$, solar radiation $(L)$ and tide regime $(H)$. Only significant variables are shown. $T_{\text {ser }}$ : mean temperature $\left({ }^{\circ} \mathrm{C}\right)$ along the time series

\begin{tabular}{|c|c|c|c|c|c|}
\hline Effect & \multicolumn{2}{|c|}{ Coefficient $( \pm$ SE) } & \multicolumn{2}{|c|}{$t$-statistic test } & $\mathrm{p}$ \\
\hline Constant & \multicolumn{2}{|c|}{$15.17 \pm 4.55$} & \multicolumn{2}{|c|}{3.33} & 0.00107 \\
\hline$T_{\text {ser }}$ & \multicolumn{2}{|c|}{$2.35 \pm 0.32$} & \multicolumn{2}{|c|}{7.40} & 0.00000 \\
\hline & \multicolumn{2}{|c|}{$-4.21 \pm 1.76$} & \multicolumn{2}{|c|}{-2.40} & 0.01772 \\
\hline$T \times L / T_{\text {ser }}$ & \multicolumn{2}{|c|}{$0.0003 \pm 0.00005$} & \multicolumn{2}{|c|}{5.05} & 0.00000 \\
\hline ANOVA & $\mathrm{SS}$ & df & MS & $F$-ratio & $\mathrm{p}$ \\
\hline Regression & 27253.10 & 3 & 9084.37 & 33.14 & 0.00000 \\
\hline Residual & 42494.56 & 155 & 274.16 & & \\
\hline
\end{tabular}

We observed rhythms of vertical migration of diatoms close to those described earlier (e.g. Fauré-Fremiet 1951, Palmer 1960, Perkins 1960, Hopkins 1963, Round \& Palmer 1966, Robak \& Kühl 1997, Kingston 1999). The diatoms reach their maximal concentration on the sediment surface during daytime emersions and begin to dip into the sediment with the rising tide, reaching a maximal concentration in the aphotic zone at night (Fig. 5).

Temperature and solar radiation intensity in combination with the tidal cycle are the main factors that regulate amount of epipelic microphytobenthos migration activity (Table 4). The variability of these factors is determined by recurrence: temperature and light intensity regimes have similar diurnal and seasonal rhythms. The tidal cycle in the region studied is semi-diurnal with a time alteration of $40 \mathrm{~min}$ every $24 \mathrm{~h}$ and also has a $14 \mathrm{~d}$ or semi-lunar rhythm with alternating spring and neap tides. The superimposition of the tidal and day:night cycles of different periods causes variability in the intertidal light and temperature regime and determines the migration rhythms of the diatoms.

Diatom vertical migration and division rhythms occur in an antiphase: the daytime maximum of cell abundance in the photic zone corresponds to a minimum of division activity, whereas the nighttime mini-

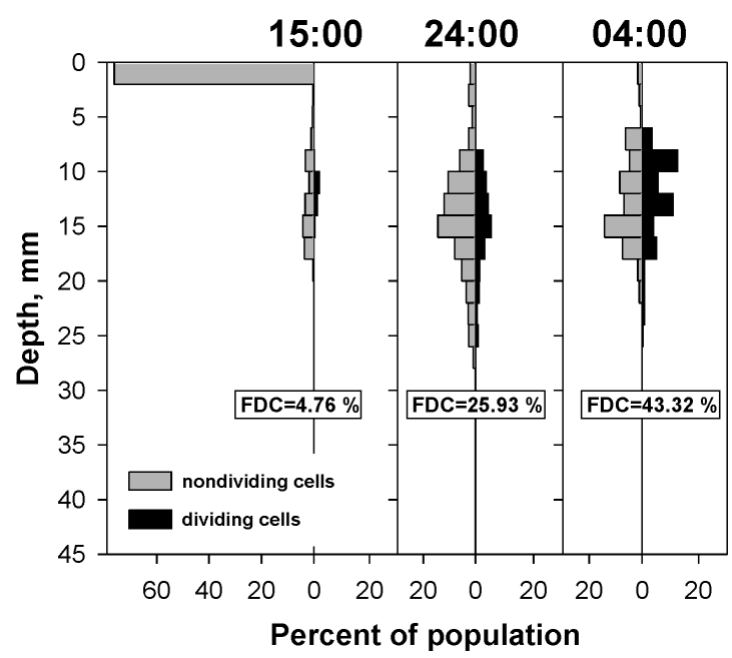

Fig. 5. Donkinia recta. Vertical distribution of nondividing (left-hand panels) and dividing (right-hand panels) cells on July $2-3,1995$, with frequency of doublet cells (FDC) dynamics. Three sediment cores were collected during daytime emersion (15:00 h), nighttime submersion (24:00 h) and nighttime emersion $(04: 00 \mathrm{~h})$ conditions from the $D$. recta local patch $\left(12.5 \times 10^{3}\right.$ cells $\left.\mathrm{cm}^{-2}\right)$ on an intertidal sandflat. The length of each bar is the percentage of the total population found in each depth interval 
Entomoneis paludosa

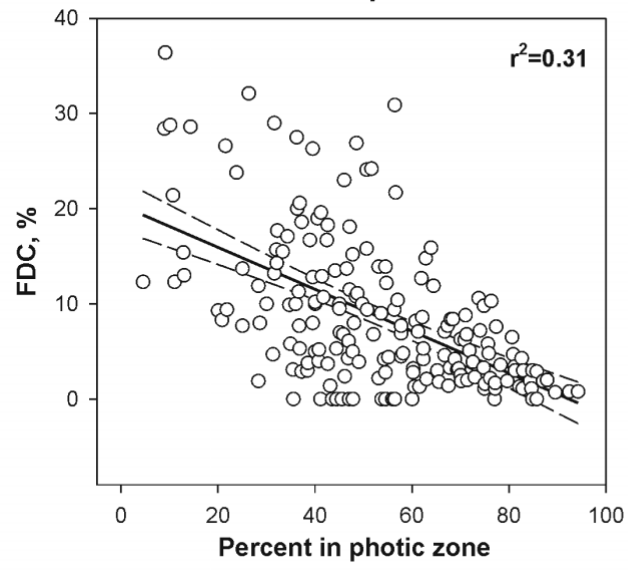

Pleurosigma aestuarii

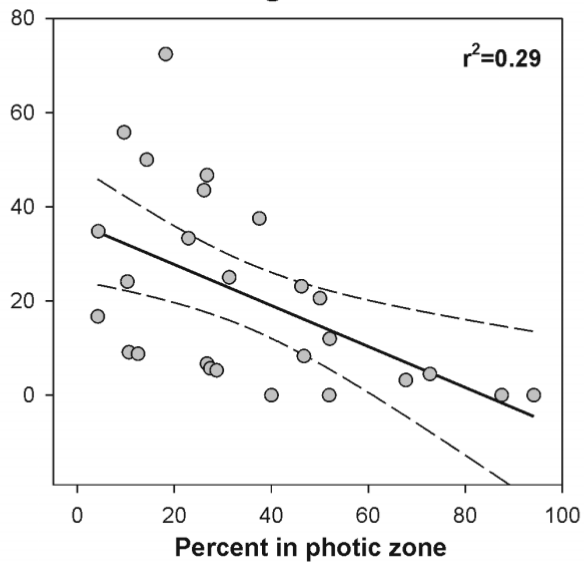

Donkinia recta

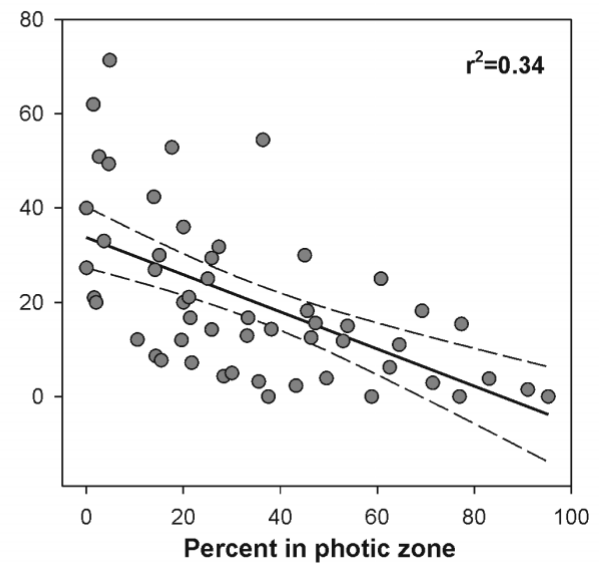

Fig. 6. Entomoneis paludosa, Pleurosigma aestuarii and Donkinia recta. Relationships between frequency of doublet cells (FDC) versus relative abundance in photic zone. Dashed lines denote $95 \%$ confidence interval

mum of cells on the surface corresponds to the peak of division in the aphotic zone (Figs. 5 \& 6).

Previous reports have shown how the nutrient properties of porewater from the deep layers of the intertidal sediments (Polikarpov \& Saburova 1990) or from the reduced zone of the Black Sea (Polikarpov et al. 1986) affect the development of diatom algae. In our field work, we identified dividing diatom cells exclusively at a depth of several $\mathrm{cm}$ in oxygen-free and strongly reducing conditions. However, the results showed that these conditions were not necessary for microalgal division (Table 5). Apparently, microalgae can find the necessary nutrient concentrations for their successful development in the most acceptable forms $\left(\mathrm{NH}_{4}{ }^{+}\right.$instead of $\mathrm{NO}_{3}{ }^{-}$) only in the deep layers of the sediment (Fenchel 1969) and, as a consequence, microalgae have to develop resistance to potential unfavourable factors in this zone (Moss 1977).
Preliminary work on the response of the epipelic microphytobenthos to changes in the vertical structure has shown that any physical disturbance will prevent cell division, although microalgae continue to migrate (Saburova 1995).

Our data support the hypothesis that migration activity of diatom algae is a forced adaptation, which permits cells to consume energy and to divide under optimum conditions in the spatially disconnected zones.

Comparing the diatom migration activity in 2 separate layers, it is necessary to remember that the less stable photic layer is part of both the sediment-water and sediment-air interface. As such, the photic layer is exposed to dramatic changes in environmental factors, and to significant grazing pressure (the socalled 'stressful zone'). However, the photic layer is also the zone where microalgae photosynthesis takes

Table 5. Entomoneis paludosa. Division intensity under experimental conditions. A: natural photic layer (3 mm); B: sterilized sand $(1 \mathrm{~cm}) ;(/)$ : plankton net material (monyl, $200 \mu \mathrm{m}) ;(/ /)$ : Nuclepore polycarbonate filter $(2 \mu \mathrm{m})$

\begin{tabular}{|c|c|c|c|c|c|c|}
\hline \multirow{2}{*}{$\begin{array}{l}\text { Exposure } \\
\text { time } \\
\text { (h) }\end{array}$} & \multicolumn{2}{|c|}{$\mathrm{A} / \mathrm{B}$} & \multicolumn{2}{|c|}{$\mathrm{B} / / \mathrm{A} / / \mathrm{B}$} & \multicolumn{2}{|c|}{ Intact core of natural sediment } \\
\hline & $\mathrm{Eh}(\mathrm{mV})$ & FDC (\%) & $\operatorname{Eh}(\mathrm{mV})$ & $\mathrm{FDC}(\%)$ & $\begin{array}{c}\text { Eh }(\mathrm{mV}) \\
0 \mathrm{~cm}: 2 \mathrm{~cm}\end{array}$ & FDC $(\%)$ \\
\hline \multicolumn{7}{|c|}{ Water from sea surface } \\
\hline 0 & 103:152 & 0.0 & $152: 103: 152$ & 0.0 & $103: 47$ & 3.2 \\
\hline 42 & $140: 2$ & 0.0 & $102: 80: 45$ & 0.0 & $105: 26$ & 4.9 \\
\hline 53 & $117: 24$ & 0.0 & $156: 135: 24$ & 0.0 & $152: 64$ & 12.6 \\
\hline 67 & $150: 52$ & 0.0 & $117: 30: 70$ & 0.0 & $112: 13$ & 7.6 \\
\hline 76 & $152: 28$ & 0.0 & $112: 10: 42$ & 0.0 & $142: 58$ & 4.2 \\
\hline \multicolumn{7}{|l|}{ Porewater } \\
\hline 0 & $103: 63$ & 0.0 & $63: 103: 63$ & 0.0 & & \\
\hline 42 & $94: 14$ & 1.5 & $102: 0: 7$ & 18.0 & & \\
\hline 53 & 89:18 & 7.2 & $160: 125: 110$ & 26.2 & & \\
\hline 67 & $112: 47$ & 3.4 & $106: 86: 39$ & 9.2 & & \\
\hline 76 & $87: 35$ & 0.0 & $112: 10: 22$ & 17.6 & & \\
\hline
\end{tabular}




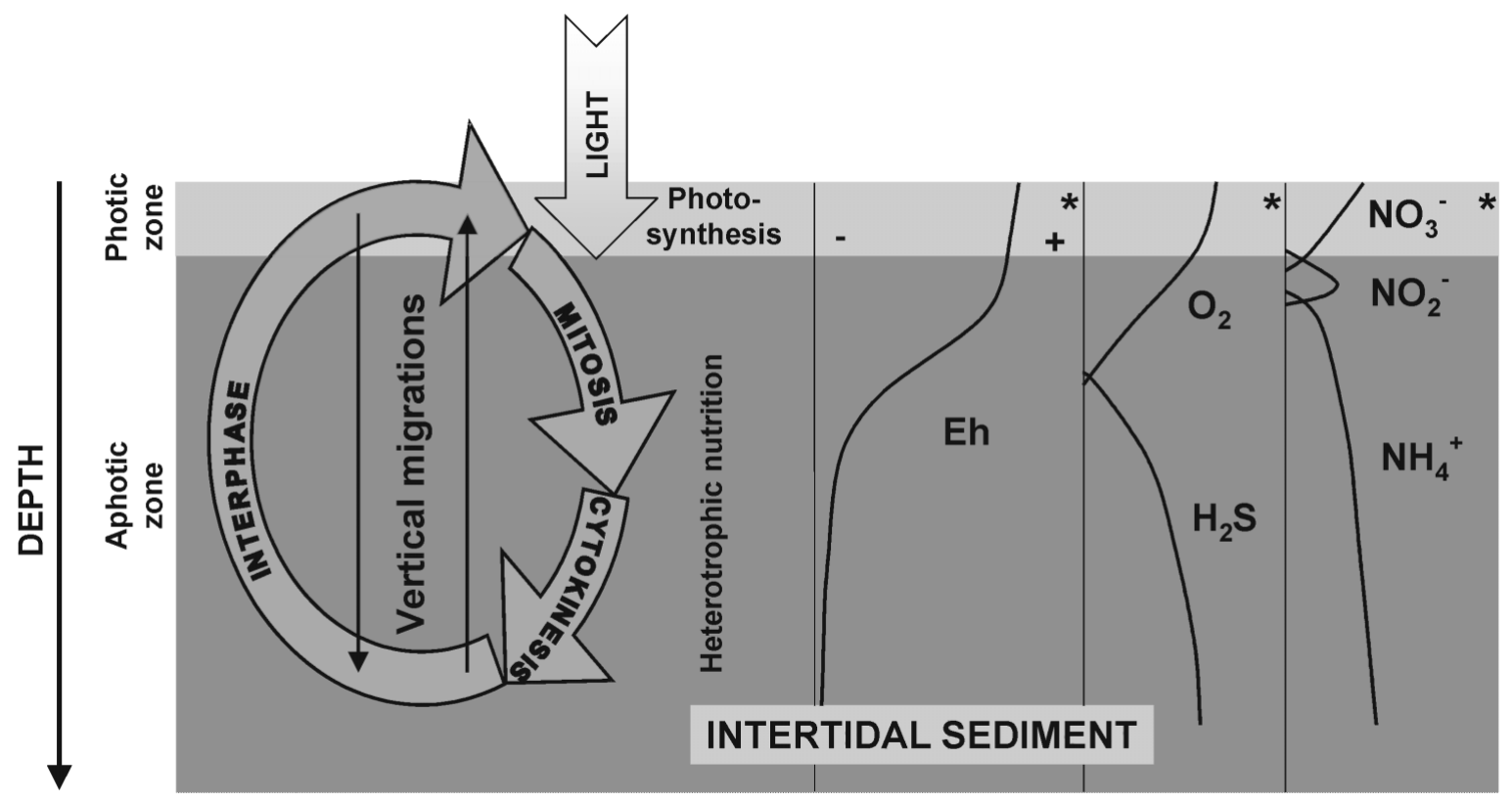

Fig. 7. Principal scheme of epipelic diatoms activity within intertidal soft sediments (*: adapted from Fenchel 1969)

place. The dynamics of such competing forces result in a constant movement of epipelic microalgae within the sediment, as if they are 'searching' for the optimum zone along the gradient of these factors.

\section{CONCLUSIONS}

Vertical stratification of the sediment, as well as the ability of microalgae to actively migrate vertically with a cycle close to circadian rhythms, are the factors determining the distribution of epipelic diatoms within the sediment.

These new observations, i.e. that epipelic diatom cells divide exclusively in the aphotic zone and that cytokinetic cells are absent from the surface of the sediment, demonstrate that the vertical migration of these microalgae allows them not only to avoid unfavourable conditions, but also to move into the deep layers of the sediment, which are, for several reasons, the necessary locations for mitosis and cytokinesis.

The results from our study and from previous studies have been combined and presented as a general scheme to illustrate our hypothesis (Fig. 7).

The migration behaviour of epipelic diatoms is regulated by 2 complex factors, an exogenous one (the set of intertidal flat environmental conditions) and an endogenous one (the cell cycle). The cells born as a result of division at a depth of 2 to $3 \mathrm{~cm}$ need energy and nutrition to continue their cell cycle. Energy is accumulated during photosynthesis in the photic zone of the sediments. However, the optimum conditions for photosynthesis develop at the sediment surface during daytime emersion. There are 1 or 2 short periods of about $4 \mathrm{~h} \mathrm{~d}^{-1}$ when the optimum conditions for migration are present and all the cells that have completed mitosis begin to move upwards. Having accumulated sufficient energy during photosynthesis, most of the microalgae migrate into the deep layers of the sediment at the beginning of submersion, i.e. evening.

Cells in the deep layers of the sediment find themselves in more favourable conditions for cell cycle development. Heterotrophic metabolism (Bunt 1969, Hellebust \& Lewin 1977) enables them to obtain the necessary substances for their growth from DOM-rich porewater (Landén \& Hall 1998) as opposed to nutrient-deficient surface water. The specific physical and chemical conditions in the deep sediment layers produce inorganic nutrients in more reduced forms (Fenchel 1969, Martens et al. 1978, Langner-van Voorst \& Höpner 1996), making their consumption more energetically profitable (Parsons \& Harrison 1983). All these factors contribute to successful cell growth and division. After division, the cells remain in the deep layers of the sediment waiting for the next period of migration to the surface (Fig. 7).

The process of cyclic migration is not totally synchronic: some of the cells are always in antiphase to the general flow, remaining in the aphotic zone when the main body migrates to the surface, and vice versa. Biological rhythms do not determine the behaviour of an organism in a concrete situation, but play the role of a barrier, ruling out the possibility of a particular behavioural act under particular concrete conditions. 
The concrete conditions and the internal readiness of the organism regulated by its biological clocks (cell cycle) determine the degree of behavioural expression (Aschoff 1981).

Natural populations of microalgae differ significantly from synchronized laboratory cultures. Separate cells within the sediment can gain an advantage due to an irregular microdistribution of different environmental factors, and take the lead in development as compared to their neighbours and vice versa. However, instead of a continuous rotation of cells in different stages of their cell cycles, we observe synchronic related to the regulating effect of exogenous rhythms. In other words, the end of mitosis starts the cycle, and environmental factors regulate cycle rate and cell behaviour in the process.

Acknowledgements. The authors express their appreciation to Prof. Kirill M. Khailov (Institute of Biology of the Southern Seas), Dr. Andrey Azovsky (Moscow State University) and Mr. Sergey Kropotov (Marine Hydrophysical Institute) for criticism, and Dr. Sc Ludmila V. Iliyash (Moscow State University) for her fruitful cooperation. We thank Dr. Michael J. Wade (Wade Research) for English language text improvement and Mrs. Marina Fadeeva for helpful comments on the manuscript. Critical evaluations of and valuable suggestions regarding an earlier version of the manuscript by 4 anonymous reviewers were extremely helpful. We are very grateful to Prof. Otto Kinne and the Otto Kinne Foundation for support of the present work.

\section{LITERATURE CITED}

Aschoff J (1981) Review of biological rhythms. In: Aschoff $J$ (ed) Biological rhythms. Plenum Press, New York, p 12-21

Baillie PW, Welsh BL (1980) The effect of tidal resuspension on the distribution of intertidal epipelic algae in an estuary. Estuar Coast Shelf Sci 10:165-180

Branch SM, Pringle A (1987) The impact of the sand prawn Calianassa kraussi Stebbing on sediment turnover and bacteria, meiofauna, and benthic microflora. J Exp Mar Biol Ecol 107:219-235

Brown DN, Gibby CE, Heckman H (1972) Photosynthetic rhythms in epipelic algal populations. Br Phycol J 7:37-44

Bunt JS (1969) Observation on phytoheterotrophy in a marine diatoms. J Phycol 5:26-34

Burkovsky IV (1992) Structural and functional organization and stability of marine benthic communities. Moscow University Press, Moscow (in Russian)

Cox E (1981) Observation on the morphology and vegetative cell division of the diatom Donkinia recta. Helgol Meeresunters 34:497-506

Fauré-Fremiet E (1951) The tidal rhythm of the diatom Hantzschia amphioxys. Biol Bull (Woods Hole) 100(1): 173-177

Fenchel T (1969) The ecology of marine microbenthos. IV. Structure and function of the benthic ecosystem, its chemical and physical factors and the microfauna communities with special reference to the ciliated Protozoa. Ophelia 6: $1-182$

Fenchel T, Straarup BJ (1971) Vertical distribution of photo- synthetic pigments and the penetration of light in marine sediment. Oikos 22:172-182

Ganaparti PN, Lakshmanu RMV, Subba RDV (1959) Tidal rhythms of some diatoms and dinoflagellates inhabiting on the intertidal sands of the Visakhapatnam beach. Curr Sci 28:450-451

Gargas E (1970) Measurements of primary production, dark fixation and vertical distribution of the microbenthic algae in the Øresund. Ophelia 8:231-253

Gargas E (1971) 'Sun-shade' adaptation in microbenthic algae from the Øresund. Ophelia 9:107-112

Grøntved J (1962) Preliminary report on the productivity of microbenthos and phytoplankton in the Danish Wadden Sea. Medd Dan Fiskeri Havunders NS 3:347-348

Guarini JM, Blanchard GF, Gros Ph, Gouleau D, Bacher C (2000) Dynamic model of the short-term variability of microphytobenthic biomass on temperate intertidal mudflat. Mar Ecol Prog Ser 195:291-303

Hellebust JA, Lewin J (1977) Heterotrophic nutrition. In: Werner D (ed) The biology of diatoms. University of California Press, Berkeley, CA, p 169-197

Hopkins JT (1963) A study of the diatoms of the Ouse estuary, Sussex. 1. The movement of the mudflat diatoms in response to some chemical and physical changes. J Mar Biol Assoc UK 43:333-341

Jensen WA (1962) Botanical histochemistry: principles and practice. WH Freeman, San Francisco, CA

Kingston MB (1999) Wave effects on the vertical migration of two benthic microalgae: Hantzschia virgata var. intermedia and Euglena proxima. Estuaries 22:81-91

Landén A, Hall Per OJ (1998) Seasonal variation of dissolved and absorbed amino acids and ammonium in near-shore marine sediment. Mar Ecol Prog Ser 170:67-84

Langner-van Voorst I, Höpner T (1996) Horizontal and vertical inhomogeneity of nutrient concentrations in porewater of an intertidal sandflat (Gröninger Plate, Rückseitenwatt von Spiekeroog, südliche Nordsee). Senckenbergiana Marit 26:179-194

MacIntyre HL, Geider RJ, Miller DC (1996) Microphytobenthos: the ecological role of the 'secret garden' of unvegetated, shallow-water marine habitats. I. Distribution, abundance and primary production. Estuaries 19:186-201

Marshall N, Oviatt CA, Skauen DM (1971) Productivity of the benthic microflora of shoal estuarine environments in Southern New England. Int Rev Ges Hydrobiol 56: 947-955

Martens CS, Berner RA, Rosenfield JK (1978) Interstitial water chemistry of anoxic Long Island Sound sediments. Limnol Oceanogr 23:605-617

Moss B (1977) Adaptation of epipelic and epipsammic freshwater algae. Oecologia 28:103-108

Palmer JD, Round FE (1967) Persistent vertical-migration rhythms in benthic microflora. VI. The tidal cycle and diurnal nature of this rhythms in the diatom Hantzschia virgata. Biol Bull (Woods Hole) 132:121-134

Pamatmat MM (1968) Ecology and metabolism of a benthic community on an intertidal sandflat. Int Rev Ges Hydrobiol 53:211-298

Parsons TR, Harrison PJ (1983) Nutrient cycling in marine ecosystems. In: Lange OL, Nobel PS, Osmond CB, Ziegler $\mathrm{H}$ (eds) Encyclopedia of plant physiology: physiological plant ecology IV, Vol 12D. Springer-Verlag, Berlin, p 85-115

Paterson DM, Underwood GJC (1990) The mudflat ecosystem and epipelic diatoms. Proc Bristol Nat Soc 50:74-82

Perkins EJ (1960) The diurnal rhythm of the littoral diatoms of the River Eden estuary, Fife. J Ecol 48:725-728 
Pickett-Heaps JD (1998) Cell division and morphogenesis of the centric diatom Chaetoceros decipiens (Bacillariophyceae) I. Living cells. J Phycol 34:989-994

Polikarpov GG, Lazorenko GE, Lanskaya LA (1986) Response of plankton algae (Bacillariophyta and Pyrrophyta) to water medium from reduced zone of the Black Sea. Proc Acad Sci USSR, Ser B 8:73-75 (in Russian)

Polikarpov IG, Saburova MA (1990) Growth of benthic microalgae in water from reduced zone of intertidal sediments. Proc Acad Sci USSR 310:253-256 (in Russian)

Riaux-Gobin C (1985) Variation temporelles des sels nutritifs et des pigments chlorophylliens dans l'eau interstitielle d'une vase estuarienne de Bretagne nord. Cah Biol Mar 26:109-124

Robak M, Kühl M (1997) Vertical migration of microphytobenthos in intertidal sediments influence of light and water content investigated with different methods. In: Flemming BW, Delafontaine MT, Liebezeit G (eds) Abstract volume of the Int Senckenberg Conf 'Muddy coast '97', September 1997, Wilhelmshaven, Germany. Forschungszentrum Terramare Berichte 2:97-98

Round FE (1979) Occurrence and rhythmic behavior of Tropidoneis lepidoptera in the epipelon of Barustable Harbor, Massachusetts, USA. Mar Biol 54:215-217

Round FE, Palmer JD (1966) Persistent, vertical-migration rhythms in benthic microflora: II. Field and laboratory studies on diatoms from the banks of the River Avon. J Mar Biol Assoc UK 46:191-214

Editorial responsibility: Otto Kinne (Editor),

Oldendorf/Luhe, Germany
Saburova MA (1995) Microphytobenthic spatial distribution in an intertidal mud-sandflat of the White Sea. PhD thesis, Moscow State University, Moscow (in Russian)

Saburova MA, Polikarpov IG, Burkovsky IV (1995) Spatial structure of an intertidal sandflat microphytobenthic community as related to different spatial scales. Mar Ecol Prog Ser 129:214-232

Serôdio J, Marques da Silva J, Catarino F (1997) Nondestructive tracing of migratory rhythms of intertidal benthic microalgae using in vivo chlorophyll a fluorescence. J Phycol 33:542-553

Serôdio J, Catarino F (2000) Modelling the primary productivity of intertidal microphytobenthos: time scales of variability and effects of migratory rhythms. Mar Ecol Prog Ser 192:13-20

Steele JH, Baird IE (1968) Production ecology of a sandy beach. Limnol Oceanogr 13:14-25

Steele JH, Munro ALS, Giese GC (1970) Environmental factors controlling the epipsammic flora on beach and sublittoral sands. J Mar Biol Assoc UK 50:907-918

Uhlig G (1968) Quantitative methods in the study of interstitial fauna. Trans Am Microsc Soc 87:226-232

Vaulot D, Olson RJ, Chisholm SW (1986) Light and dark control of the cell cycle in two marine phytoplankton species. Exp Cell Res 167:38-52

Wasmund N (1969) Vertical distribution of chlorophyll $a$ and diatom algae in bottom sediments. Int Rev Ges Hydrobiol $14: 369-375$

Submitted: July 12, 2001; Accepted: November 19, 2002

Proofs received from author(s): March 25, 2003 